Ана М. Јовановић

Универзитет у Београду

Филолошки факултет

e-mail: jovanna762004@yahoo.com

https://doi.org/10.18485/ai_san_o_gradu.2020.ch15

821.581.09-31

Оригинални научни рад

\title{
У ЗАГРЉАЈУ МАШТЕ И РЕАЛНОСТИ - МО ЈЕНОВ ГАОМИ
}

Гаоми није само град у провинцији Шандунг и родно место кинеског нобеловца Мо Јена, већ и позорница на којој се одвија радња његових дела, исходиште и уточиште свих његових промишљања, прича и ликова. У духу магичног реализма, Мо Јен га је саткао од реалног и фантастичног чије нити није тако лако раздвојити.

У овом раду покушаћемо да, анализом описа у Мо Јеновим романима Жабе и Смрт на сандаловом коиу, као и есеју „Зид који је умео да пева“, покажемо да Гаоми у Мо Јеновој прози није само веран опис његових сокака, кућа и храмова, већ, што је много важније, и место препуно легенди, оперских арија, локалних обичаја и уметности, које је Мо Јен тако вешто пригрлио и уградио у своје „књижевно краљевство“

Кључне речи: Мо Јен, Гаоми, магични реализам, „књижевно краљевство“.

Кинески нобеловац Гуан Моје (管谟业), најширој публици познат под књижевним именом Мо Јен (莫 言) рођен је 1955. године у једном сеоцету североисточно од града Гаомија, смештеног недалеко од велике поморске луке и вишемилионског града Ћингдаоа у 
источној кинеској провинцији Шандунг. ${ }^{6}$ Као изузетно плодан писац он је за своје књижевно стваралаштво, осим најпрестижније Нобелове награде за књижевност (2012. године), у Кини награђен и најзначајнијом, Мао Дуновом наградом (2011. године) (Павловић, 2013: 511). Због Мо Јеновог специфичног начина приповедања у коме реалне описе неретко обогаћује фантазмагоричним детаљима, а историјске чињенице легендарним ликовима, изучаваоци његовог дела суочени су с тешкоћом приликом утврђивања књижевног правца коме припада. Дунг Гуођун (Dong Guojun) сматра да би Мо Јеново стваралаштво требало сврстати у „халуцинатни реализам“ (hallucinatory realism), што је уосталом, урадила и шведска Академија у објашњењу одлуке да му се додели Нобелова награда (Dong 2012: 125), мада ће га највећи број критичара ипак сврстати у представнике магичног реализма.

Мо Јенова вечна инспирација и позорница на којој се одиграва радња већине његових дела јесте Гаоми, или шире Североисточни Гаоми. ${ }^{7}$ У овом раду ћемо, преко анализе описа Гаомија датих у Мо Јеновим романима Жабе (у Кини објављен 2009. године), Смрт на сандаловом коиу (у Кини објављен 2001. године) и есеју „Зид који је умео да пева“ покушати да покажемо да је Гаоми у Мо Јеновој прози, подједнако стваран као и онај који можемо посетити, чије фотографије можемо видети и о коме можемо читати у новинским чланцима. Гаоми, да-

6 Изузетно интересантан опис своје посете овом сеоцету, Мо Јенове родне куће и односа који су сељани имали према њему пре и после Нобелове награде дала је Ли Чунфенг (Li 2012).

7 Хуанг Каифа (Huang 2018:138) указује на старо порекло назива Североисточни Гаоми за област око варошице Јухеја североисточно од Гаомија, који се користио у периоду од династије Минг (1368-1644) до периода Републике (1912-1949). 
кле, не постоји само у својим грађевинама, ужурбаним корацима његових мештана и повицима уличних продаваца, већ и у начину на који га доживљава и о њему говори овај велики писац.

У овом раду приклањамо се ставу Сунг Сјуећинга и Џанг Лиђуна (Song Xueqing, Zhang Lijun), који кажу „да није спорно то да ли родно место утиче на књижевно стваралаштво неког писца или не, већ у којој мери то чини“ (2015:160). А Гаоми је, у сваком погледу, на Мо Јена имао огроман утицај. У том смислу, кроз Мо Јенов опис родног места, између осталог, може се видети и социо-економски развој његовог завичаја од ненасељене пустаре, преко села, све до града (ibid.). Погледајмо следеће одломке у којима се врло јасно види та промена која је у његовом родном месту наступила:

Родио сам се у оном сеоцету ито тежи на југоисточном ободу Североисточног Гаомија. Неколико десетина сеоских породица и неколико десетина земьаних кућерака с тршчаним крововима разбацано је у загрльај реке Бијао. Село је, иако мало, имало широки прапорни друм, дуж којег су, раштркане с обе стране расле софоре, жалосне врбе, чемпреси, кинеске каталпе, и још по које чудно дрво чије име нико не зна а које се са златастом јесени цело заодене жутим тишћем. [...] („Зид који је умео да пева“ 2012: 139)

[...] Да не идемо ни у обилазак сваког понаособ оних већих и маних сеоца што леже на територији Северочсточног Гаомија? Велики казани за печене ракије, радионице за бојене тканине, стакленици за узгој пилића, старии који су тренирали орлове, старе ткале, мајстори што су итавили кожу, места на којима се приповедало о духовима, и све друго што је чинило тамошюу прошлост, и дале постоји наталожено у стеновитим слојевима историје, и 
никуда неће побећи. [...] („Зид који је умео да пева“ 2012: 148)

[...] За само неколико месеци, обишао сам сва насеља која су се налазила на северној обали реке. Трагови мојих стопала остали су у шумама, вртовима, малим и великим супермаркетима, масерским радюама, јавним местима за рекреацију, козметичарским салонима, апотекама, киосичма за продају игара на срећу, тржницама, салонима за продају намештаја и зеленим пијацама поред реке. ${ }^{8}$ [...] (Жабе 2013:335-336)

Први одломак може се протумачити као опис Североисточног Гаомија из неких прошлих времена, из Мо Јеновогдетињства кадајето место преличило нанеки заселак него на село у правом смислу те речи. С друге стране, с обзиром на то да се у другом опису помињу разна занимања, могли бисмо рећи да писац ту описује сада већ развијеније село с комплекснијом друштвеном структуром. Трећи одломак представља верни приказ изгледа Гаомија 2009. године када је објављен роман Жабе. Ипак, да ли је сваки Мо Јенов приказ родног места овако реалистичан? Анализирајући његово стваралаштво, Џоу Леи (Zhou Lei) истиче да се Mo Јенова дела могу поделити на она у којима преовлађују описи невероватних догађаја и фантастичних прича о Североисточном Гаомију, она у којима се писац држи реалистичних описа тог места и догађаја у њему, али и она у којима је магично и мистично измешано с реалистичним и истинитим (Zhou 2017: 60, 61). Она цитира Мо Јенов став према завичају, изнет у тексту „О себи“(自述), који је објављен у часопису Cuјаошуо пинглун (小说评论) 2002. године, који каже:

8 Сви цитати дати у тексту ауторкин су превод с кинеског језика. 
Североисточни Гаоми није географски већ кюижевни концепт, отворен, а не затворен. Ту землу снова осмислио сам ослатьајући се на искуства из сопственог детинства и настојећи да од юе створим Кину у малом.[...] (Zhou, 2017:57)

Тунг Ћингбинг (Tong Qingbing), иначе Мо Јенов ментор на магистарским студијама које је завршио на Пекиншком Нормал универзитету (Beijing Normal University), наводи Мо Јенов став о улози коју завичај игра у његовом књижевном стваралаштву:

Пишчев завичај понајвиче је једна земља снова саткана од сећана на прошла времена. Заснована на историјски гледано реалним догађајима, у тај уснивени завичај засађено је небројено много ивећа и травки, којима писаи непрестано додаје нове гране и гранчице, баш као што то ради и приповедач бајки, не би ли привукао читаоиа. У том настојату да родни крај претвори у сновиђеюе и испуни га осећатима, проклијавају жељь а а тај исти завичај превазиће и нада у могућност да у томе yсnе. (Мо Јен, 超越故乡, 1994:30, видети у Tong 2013:71)

Мо Јен је у том свом настојању итекако успео. Сопствено „књижевно краљевство “9 обогатио је свим оним елементима који гаомијску културу чине посебном и препознатљивом. У врло детаљној анализи у својој магистарској тези „Карактеристике гаомијске културе у Мо Јеновим романима“ (论莫言小说的高密文化特 征), Леи Жуифу (Lei Ruifu, 雷瑞福) каже „да Мо Јенове романе, без иоле оклевања можемо назвати представ-

9 Термин „књижевно краљевство“ (文学王国) среће се код многих кинеских аутора, између осталог и Дунг Гуођуна (Dong 2012:127), премда има и оних, попут Леи Жуифу (Lei 2009: 16, 33) који поред овог користе и термин „књижевна република Гаоми“(高密文学共和国). 
ницима гаомијске културе“ управо зато што је у њима описано много њених елемената: церемоније сахрањивања, локална опера, локални усеви итд. (2009:9), биљни и животињски свет, природни пејзажи (2009: 13) и посебно поља црвеног сирка „с којима је Гаоми нераскидиво повезан“ (2009: 16). Гаомијску културу прожимају: несаломива воља за животом, жестоки дух отпора и дечија искреност и наивност (Lei 2009: 10,11) тј., управо оне одлике које су заједно са личним искуствима кроз која је прошао формирале Мо Јенов специфичан стил писања. Као део средине из које је потекао али и због глади која га је пратила у детињству, честих природних непогода у Гаомију, традиције друмских бандита, напуштања школе, усамљености на пашњацима док је чувао стоку као и слушања и читања локалних легенди о аветима и духовима, и Мо Јен је попримио карактеристике локалне културе па се у њему ствара „снажна жеља за животом и упорна вера у преживљавање“, „дух отпора“ и „жеља за повратак природном стању и дечијој знатижељи (ibid: 11, 12). Зато је Гаоми место чији становници деци дају имена по деловима тела (на пример Стопалан, Жучка, Џигеран, Носоња, Зубало, Срчана итд.) чему је „кумовало веровање да 'они с простијим именима дуже живе“ (Жабе 2013:13); у коме сеоски вајар и истовремено улични продавац глинених луткица са̂м бира ону коју ће вам продати у чему га води сопствена процена брачног пара који жели да их купи, играјући тако својеврсну улогу пророка, јер би дете које би се том пару касније родило, заиста личило на глинену фигурицу бебе (Жабе 2013: 144-145); у коме су „'старе примаље' [...], док су оклагијама притискале трбух у покушају да дете истисну напоље, трудницама прљавом крпом затварале уста, као да дете може кроз уста да излети’[...]“ (Жабе 2013: 23), а деца која немају 
шта друго јести, глад ублажавала тако што су јела угаљ (Жабе 2013: 19); Гаоми је место, вероватно једино те врсте на свету, где се организује „снежна пијаца“ о којој Мо Јен каже следеће:

[...] Тамо ти је дозвољено да гледаш, можеш покретима руку да објашнаваш, све своје мисли усредсредиш да упијеш то искуство, али никако не смеш да отвориш уста и проговориш. [...] Све до једне, жене широким рукавима прекривају уста, ито делује као да желе да се заштите од налета леденог ветра, а у ствари то раде да би спречиле речи да исиуре. Сви ми се овде придржавамо древног споразума: да ћемо ћутати. Њиме јечовек сам себе ограничио, али је, истовремено, и сам себи поставио изазов. [...] Својим сам очима у прошлости виђао како су се разне врсте купопродаја на „снежној пијаци“ чудновато брзо обавльле баш зато што није било приче. Кад због ћутана све постане једноставно и директно, јасно ти је да је деведесет и девет посто свега што се на овом свету каже чиста глупост, која се може nрећутати. („Зид који је умео да пева“ 2012: 146, 147.)

Читајући ове описе, читалац се често нађе у недоумици да ли је то што је речено само поетска стилизација нечег реално постојећег, или је „то нешто“ што Мо Јен дода својим описима не би ли их зачинио дахом мистичности. Јер, као што каже Џоу Лисија (Zhou Lixia) (2018: 131), треба направити разлику између реалног Гаомија и оног књижевног, између којих, премда постоје сличности, постоје и знатне разлике, jep је управо тај књижевни Гаоми, као платформа на којој се дешавају радње свих пишчевих дела, врло често „обогаћен, измењен, побољшан“ а понекад и вешто осмишљен убацивањем ликова и догађаја који у оном реалном нису постојали, већ их је писац ту „пресадио“ из неких других искустава. (Zhou 2018:131). 
Гаоми је истовремено и завичај хероја отпора страним завојевачима, а заправо веома често ликова сумњивог морала, какав је био Сун Бинг, локални оперски певач и вођа побуне против изградње немачке железничке пруге која ће покварити фенгшуи њиховог родног места (Смрт на сандаловом коцу 2016:19), који је због тога скончао набијањем на колац од сандаловине; будаластим ликовима попут Џао Сијаођијаа који верују да су све лепе жене заправо преображене гује које човеку, у тренутку непажње, попију мозак (Смpm на сандаловом коцу 2016: 95); бабе Џаоа, чувеног џелата који је као зрна пасуља збрајао главе оних које је посекао (Смрт на сандаловом коцу 2016: 14) и локалне лепотице Сун Меињијанг и саме вичне оперском певању, која покушава да спасе свог оца Сун Бинга. То је, такође место где се људи надмећу по лепоти својих брада (Смрт на сандаловом коиу 2016:165-173) али и позорница за чувену гаомијску оперу маоћијанг, коју вештом игром хомофоних карактера, Мо Јен у роману Смрт на сандаловом коцу назива „маоћијанг“ (мачећа опера):

\section{$[\ldots]$}

Ко из ведра неба гром, топови су загрмели, и ветар се силни подигао мијау мијау мијау радостан сам вазда био јер сам с тајком дошо да би'казну извршио [...] сандалове кочеве давно смо скували, и на живој свини смо се извежбали, мој оцо је у том највештији био, вештини ме тој тично подучио. [...] Кад наједном топ ти груну, а то рђав знак је био, преда мном се свако сада изменио. Било је то опет масло оног брка, па се испред мене створи страшна збрка. Керови и свиюе, коюи и магарии, курјаци и бубе, тигрови и пуме, чак и једну корначу у носиљии видех приде, али туди било није ни за лека нигде. Корнача Јуен чинова је имо много, ал'се 
опет с оиям мојим поредити није мого мијау мијау мијау мрнау

(Смрт на сандаловом коиу 2016:508-509)

[...]

Куку оцо, куку мајко моја куку мени душо моја мила ито си мени задовольство била јадо моја ито живот изгуби душа мени за тобом крвари

Мијаи мијау мијау мијау (Смрт на сандаловом коцу, 2016:581)

Гаоми је сасвим очигледно, место специфичних арија, или како то Јен Фенг (Yan Feng) каже, место у коме Мо Јен, „употребом боја и звукова појачава и мења перцепцију реалности, креирајући тако за читаоца једну премда измишљену, опет и реалну атмосферу“" (цитирано према Fu 2016:139).

Мо Јен најмање пажње посвећује описима савременог града Гаомија, који су у исто време и најбезличнији и најмање емотивно обојени, штавише и прилично негативни, што је вероватно, с једне стране, последица Мо Јенове привржености селу из којег потиче, а с друге, недостатак дубљих осећања према граду у чији се начин живота никако не може уклопити (Song, Zhang 2015:169). Ипак, како истиче Џоу, непобитно је то да су у делима писаним деведесетих година и оних после две хиљадите све присутнији описи града, што се може најбоље видети у романима Велика недра широка бедра, Уморан од живота и смрти и Жабе (Zhou 2017: 62). Илустроваћемо то следећим примером:

[...] Ходајући пешачком стазом на тек изграђеном косом висећем челичном мосту, пређосмо реку. Међу аутомобилима који су пролазили мостом било је пуно бе-ем-веова и мериедеса. Овај с укусом саграђени мост личио је на галеба раширених крила. С десне стране, одмах после моста, налазили су се градски терени за 
голф, а с леве надалеко чувени Храм богине плодности. (Жабе, 2013: 275)

Опис овог раскриљеног челичног моста стоји у оштром контрасту према опису „трошног каменог мостића“ из Мо Јеновог детињства у који је уписана историја његовог завичаја („Зид који је умео да пева“ 2012: 146), а луксузни аутомобили колима за вучу која су теглиле сувоњаве и тврдоглаве муле, попут оне што је Ванг Жучку ујела за главу (Жабе 2013:15). Терени за голф, с друге стране, контраст су равници по којој човеку пукне поглед кад изађе из села („Зид који је умео да пева“" 2012: 139).

Описи Гаомија расути по Мо Јеновим романима, новелама, приповеткама и есејима, попут коцкица мозаика, захваљујући неспутаној машти и вичном перу овог великог писца, граде слику овог места, које у збиљи можда није тако живописно као на папиру. Па ипак, надамо се да ће и у делима која ће уследити, као неисцрпни извор инспирације, његов завичај бити допуњаван новим детаљима који ће га, баш као што је то и сам Мо Јен рекао, претворити у сновиђење. До тада, нама остаје да покушамо да читајући његова досадашња дела и сами постанемо део тог широког загрљаја маште и реалности које Мо Јен назива именом Гаоми.

\section{Извори и литература}

Dong, Guojun. "Gaomi dongbeixiang: Mo Yan xiaoshuo de xuhuan xushi yu 'zhenshi' xijie". Theory Journal 226/12 (2012): 125-128. Електронска база података CNKI. (China National Knowledge Infrastructure - China Academic Journals Full-Text Database). Вeб. 02.10.2019.[董国俊.“高密东 北乡: 莫言小说的虚幻叙事与' 真实' 细节”. 理论学 刊，2012年第12期总第226期： 125-128.] 
Huang, Kaifa. “Cong Gaomi dongbei xiang xunsi 'Gaomi dongbei xiang”'. Masterpieces Review 1 (2018): 137-140. Електронска база података CNKI. (China National Knowledge Infrastructure - China Academic Journals Full-Text Database). Веб. 20.08.2019. [黄开发. “从高密东北乡寻思 “高密东北 乡”.名作欣赏，2018年第1期: 137-140.]

Fu, Xinqing. "Mo Yan Gaomi shijie de secai yu shengyin". Journal of Henan University (Social Science) 56/2 (2016):138-143. Електронска база података CNKI (China National Knowledge Infrastructure - China Academic Journals Full-Text Database). Веб. 20.08.2019. [付欣晴. “莫言高密世界的色 彩与声音”, 河南大学学报 (社会科学版)， 2016年第 56 卷第2期: 138-143]

He, Chengzhou. "Rural Chineseness, Mo Yan's Work, and World Literature"., Angelica Duran, Yuhan Huang (eds). Mo Yan in Context: Nobel Laureate and Global Storyteller, West Lafayette, Indiana: Purdue University Press 2014, 77-90. Веб. 25.05.2020. Доступно на: https://www.jstor.org/stable/j.ctt6wq1tk.10

Lei, Ruifu. "Lun Mo Yan xiaoshuo de Gaomi wenhua tezheng". Hebei shifandaxue (2009). (необјављена магистарска теза). Електронска база података CNKI (China National Knowledge Infrastructure - China Academic Journals FullText Database). Веб. 02.10.2019. [雷瑞福. “论莫言小说的 高密文化特征”. 河北师范大学, 2009年（未发表的硕士 论文）]

Li, Chunfeng. "Gaomi:Nuojiang zhihou”. Nanfengchuang, 20. 11. (2012) : 56-59. Електронска база података CNKI (China National Knowledge Infrastructure - China Academic Journals Full-Text Database). Веб. 02.10.2019.[李淳风.“高 密: 诺奖之后”, 南风窗, 2012.11.20: 56-59]

Li, Guo. "Mo Yan bixia de shenmi da di - Gaomi dongbei xiang". Masterpieces Review 30 (2013):55-56, 62. Електронска база података CNKI (China National Knowledge Infrastructure - China Academic Journals Full-Text Database). Веб. 02.10.2019. [李郭. “莫言笔下的神秘大地——高密东北 乡”，名作欣赏，2013，30：55-56，62]

Li, Shufang. "Mo Yan yu Gaomi de hong gaoliang wenhua". 
Shandong dang'an 1 (2014): 62-64. Електронска база података CNKI (China National Knowledge Infrastructure - China Academic Journals Full-Text Database). Веб. 02.10.2019. [李淑芳. “莫言与高密的红高粱文化”, 山东 档案，2014, 1：62-64.]

Pavlović, Mirjana. „Sjaj i beda kineskog naroda“. Žabe (2013): 509-517. Штампано.

Song, Xueqing, Zhang, Lijun. "Lun Mo Yan 'Gaomi dongbeixiang' de fangzhiti xushu celüe”. Dangdai zuojia pinglun 6 (2015) : 160-169. Електронска база података CNKI (China National Knowledge Infrastructure - China Academic Journals Full-Text Database). Be6. 20.08.2019. [宋学清, 张丽军.“ 论莫言“高密东北乡’的方志体叙述策略”, 当代作家评 论，2015年6期： 160-169.]

Tong, Qingbing. "Mo Yan de shuoshi lunwen yu Gaomi dongbeixiang wenxue wangguo". Beijing shifandaxue xuebao (shehui kexue ban) 239/5, (2013): 69-75. Електронска база података CNKI (China National Knowledge Infrastructure - China Academic Journals Full-Text Database). Веб. 25.05.2020. [童庆炳. “莫言的硕士论文与高密东北乡文学 王国”，北京师范大学学报（社会科学版）2013年第5期 （总第239期）：69-75.]

Yang, Yuanteng. “Cong 'Gaomi dongbeixiang' kan Mo Yan de xiangtu qinghuai”. Anhui wenxue 374/9 (2014): 63-65. Електронска база података CNKI (China National Knowledge Infrastructure - China Academic Journals Full-Text Database). Веб. 02.10.2019. [杨元腾. “从“高密东北乡”看 莫言的乡土情怀”, 安徽文学 (下半月)，2014年9期总 374期: 63-65.]

Zhou, Lei. "Mo Yan zai 1985: 'Gaomi dongbeixiang' dansheng kao". Xiaoshuo pinglun 2, (2017): 54-64. Електронска база података CNKI (China National Knowledge Infrastructure - China Academic Journals Full-Text Database). Веб. 20.08.2019. [周蕾. “莫言在1985: ‘高密东北乡’ 诞生 考”.小说评论, 2017(2): 54-64.]

Zhang, Lei, Li, Yue. “Touming de Gaomi dongbeixiang - qiantan Mo Yan xiaoshuo de chuangzuo sixiang". Journal of Hebei United University (Social Science Edition) 13/6 (2013) : 223- 
225. Електронска база података CNKI (China National Knowledge Infrastructure - China Academic Journals FullText Database). Веб. 02.10.2019. [张否, 李跃. “透明的高密 东北乡——浅谈莫言小说的创作思想”.河北联合大学学 报（社会科学版），2013，第13卷（第6期）：223-225] Zhou, Lixia. "Gaomi Dongbei xiang' dui Mo Yan xiaoshuo chuangzuo de yingxiang". Journal of Jilin Radio and TV University 4 (2018) (Total No. 196): 129-131. Електронска база података CNKI (China National Knowledge Infrastructure - China Academic Journals Full-Text Database). Веб. 20.08.2019. [周丽霞. “高密东北乡”对莫言小说创作的影 响”, 《吉林广播电视大学学报》, 2018年, 第4期（总 第196期）：129-131.]

Преводи:

Мо, Јен. „Зид који је умео да пева“. С кинеског превела Ана Јовановић. Београдски книжевни часопис, бр. 29, зима 2012: 139-149. Веб.25.05.2020.

Mo, Jen. Žabe. Beograd: Laguna, 2013. С кинеског превела Ана Јовановић. Штампано.

Mo, Jen. Smrt na sandalovom kocu. Beograd: Laguna, 2016. С кинеског превела Ана М. Јовановић. Штампано. 
Ana M. Jovanović

\section{THE EMBRACE OF THE IMAGINED AND REAL IN MO YAN'S GAOMI}

\section{Summary}

Gaomi is not only a town in Shandong province and the birthplace of the Nobel prize winner Mo Yan, it is also a stage on which the plots of all of his works take place. It is both the source and the final destination of all his thoughts, stories and characters. In the spirit of magical realism and through the descriptions of life, sounds and local customs, Mo Yan made Gaomi a combination of real and fantastic, so deeply intertwined, that it becomes extremely hard to distinguish one from another.

In this article and through the analysis of the descriptions Mo Yan gave in his novels Frogs and Sandalwood Death, and an essay "The Wall That Can Sing", we will try to show that Gaomi in Mo Yan's prose not only exists in the depiction of its houses, lanes and temples, but more importantly, through local customs, art, legends and operatic arias all of which Mo Yan has so cleverly embraced and built into his „literary kingdom“ called Gaomi.

Key Words: Mo Yen, Gaomi, magical realism, "literary kingdom". 